\title{
Feeding habits of the jaguar Panthera onca (Carnivora: Felidae) in Tortuguero National Park, Costa Rica
}

\author{
Stephanny Arroyo-Arce ${ }^{1 *, 2}$, Ian Thomson ${ }^{1}$, Kat $_{\text {Cutler }}^{3} \&$ Stephanie Wilmott ${ }^{3}$ \\ 1. Coastal Jaguar Conservation, 126-3100 Santo Domingo, Heredia, Costa Rica; sturnina@gmail.com, \\ ianitthomson@hotmail.com \\ 2. Panthera Costa Rica, 8-3870-1000 San José, Costa Rica \\ 3. Global Vision International/GVI Costa Rica, 230-60601 Quepos, Costa Rica; kat_cutler@outlook.com, \\ stephanie.wilmott@hotmail.com \\ * Correspondence
}

Received 12-VII-2017. Corrected 18-X-2017. Accepted 17-XI-2017.

\begin{abstract}
Although dietary studies are considered an important conservation tool, few studies have assessed jaguar (Panthera onca) diet in Costa Rica. Therefore, this study describes the diet composition of the jaguar in Tortuguero National Park, Costa Rica, carried out by analyzing and comparing carcass $(n=1374)$, scat $(n=75)$ and camera trap $(n=3)$ data, collected between 2012 and 2016. Our results indicated that jaguar diet in this area consisted of at least 20 prey species. The green sea turtle (Chelonia mydas) was the most frequent item based on carcass data, while the white-lipped peccary (Tayassu pecari) was the major prey species according to the scat analysis. Our results highlight the importance of combining different methods to describe the jaguar feeding habits. Further research should focus on calculating jaguar and terrestrial prey species abundance in the study area, information that would help to complement our findings. Rev. Biol. Trop. 66(1): 70-77. Epub 2018 March 01.
\end{abstract}

Key words: Panthera onca; Chelonia mydas; Tayassu pecari; diet; scats; carcasses; Tortuguero National Park.

The feeding ecology of the jaguar (Panthera onca) has been widely studied throughout its geographic range. These studies have allowed us to estimate jaguar diet composition (Azevedo, 2008; Rueda, Mendoza, Martínez, \& Rosas-Rosas, 2013) and better understand a) jaguar-prey relationship (Weckel, Giuliano, \& Silver, 2006; Arroyo-Arce \& Salom-Pérez, 2015), b) jaguar prey preference (Hayward et al., 2016), c) jaguar impact on prey population (Arroyo-Arce \& Salom-Pérez, 2015), d) interspecific competition between jaguar and other felids (Moreno, Kays, \& Samudio, 2006, Gómez-Ortiz, Monroy-Vilchis, \& MendozaMartínez, 2015) and e) human-jaguar conflict (Azevedo, 2008; Cavalcanti \& Gese, 2010).

The most commonly used technique of these studies has been analysis of scat samples, with other methods such as examination of carcasses used less frequently. These noninvasive techniques can be of great value when studying cryptic and endangered species such as the jaguar, since it is not necessary to capture the animal (Waits \& Paetkau, 2005; Perilli, Lima, Rodrigues, \& Cavalcanti, 2016). Klare, Kambler and Macdonald (2011) also emphasized that non-invasive techniques are relatively simple and affordable compared with other methods (e.g. stomach content). However, some disadvantages such as the low sample size and poor detectability of prey remains, must be considered to avoid biased or spurious results (Foster, Harmsen, \& Doncaster, 2010; Tambling et al., 2012; Steenweg, Gillingham, Parker, \& Heard, 2015; Morin et al., 2016).

In Costa Rica, only six studies have described jaguar diet through scat analysis (Chinchilla, 1997; Bustamante, 2008; Carrillo, 
Fuller, \& Saenz, 2009; Corrales \& Cardenal, 2008; Gonzales-Maya, Navarro-Arquez，\& Shipper, 2010; Montalvo, 2012). In Corcovado National Park, Chinchilla (1997) and Carrillo et al. (2009) determined that the white-lipped peccary (Tayassu pecari) was one of the main prey species for the jaguar. For its part, Bustamante (2008) documented that the white-lipped peccary, the two-toed sloth (Choloepus hoffmanni) and the coati (Nasua narica) were the main items found in Golfo Dulce Forest Reserve in the Osa Peninsula. Corrales and Cardenal (2008) and Gonzalez-Maya et al. (2010) determined that the collared peccary (Pecari tajacu) and the ocelot (Leopardus pardalis) were the most common prey species in Talamanca. While Montalvo (2012) reported a preference for white-tailed deer (Odocoileus virginianus), collared peccary and the olive ridley sea turtle (Lepidochelys olivacea) in Santa Rosa National Park. Likewise, few studies have used data from carcasses presumed killed by jaguars to describe its food habits. For example, researchers in Corcovado National Park (Carrillo et al., 2009), Tortuguero National Park (Veríssimo, Jones, Chaverri, \& Meyer, 2012; Arroyo-Arce \& Salom-Pérez, 2015) and Santa Rosa National Park (Alfaro et al., 2016) found sea turtles to be important prey items in the jaguar diet.

The present study expands the current knowledge of jaguar diet in Tortuguero National Park, Costa Rica. Previous research in this area has focused on the predator-prey interaction between the jaguar and the local nesting population of sea turtles (Veríssimo et al., 2012; Arroyo-Arce \& Salom-Pérez, 2015). Although these studies highlighted the importance of the green sea turtle (Chelonia mydas) as a food source for the local jaguar population, the role of other prey species is still unknown.

\section{MATERIALS AND METHODS}

Study site: The study area was defined by approximately $29 \mathrm{~km}$ of coastline located within Tortuguero National Park, Costa Rica (10³2’28' N - 83030'08' W). This site, known as Tortuguero beach, extends from the
Tortuguero River mouth in the North to the Jalova River mouth in the South; there is also a human-made trail running parallel and along the entirety of the beach (Fig. 1). A Tropical Wet Forest (Holdridge, 1969) borders the entire study site except for a coconut plantation and cattle ranch to the South, and Tortuguero village to the North end. The average temperature ranges from 25 to $30{ }^{\circ} \mathrm{C}$, with a mean annual precipitation of $6000 \mathrm{~mm}$ (Bermúdez \& Hernández, 2004).

Data collection and analysis: Carcass data of potential prey species, believed to have been predated by a jaguar, was collected by carrying out weekly surveys along Tortuguero beach, from July 2012 to November 2016. Additional information was also collected opportunistically while the researchers surveyed the human-made trails surrounding the study area. When a carcass was discovered, the carcass was examined for evidence of jaguar predation (e.g. bite marks on the neck, drag marks). If determined that a jaguar was responsible for the kill, the following information was recorded: date of discovery, geographic coordinates and species identification of the carcass (for more details on the methodology see Arroyo-Arce \& Salom-Pérez, 2015).

Jaguar scats were collected, while performing the carcass data collection, along the beach and trails, from August 2012 to December 2016. Upon discovery, the sample was collected in a plastic bag labeled with the date of collection and geographic coordinates. Jaguar scats were differentiated from other wild cats and carnivores based on their morphological characteristics (Aranda, 2000) and associated signs (e.g. nearby jaguar tracks). It is important to highlight that samples were not collected when it was not possible to say with certainty that they belonged to jaguars.

Each scat was soaked in a solution of water and detergent for up to 48 hours. After this period, the scat was washed with running water over fine-mesh filters and sun dried. Once dried, the non-digested prey remains (e.g. claws, tissue, hair) were separated and later identified 


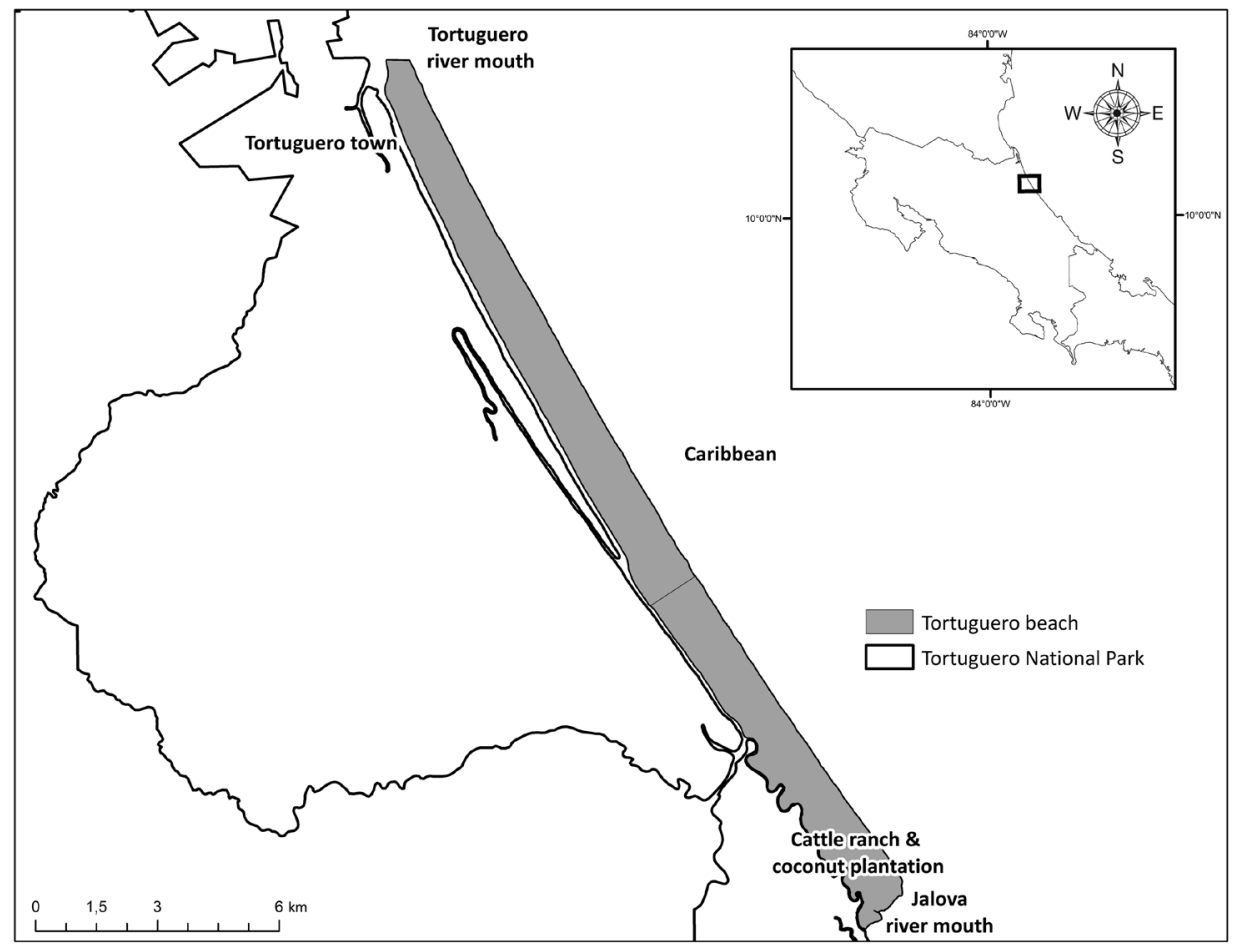

Fig. 1. Tortuguero beach location, Tortuguero National Park, Costa Rica.

to the lowest possible taxonomic level using specialized guides (Baca \& Sánchez-Cordero, 2004; Pech-Canché, Sosa-Escalante, \& Koyoc, 2009; Juárez et al., 2010) and specimens from scientific collections. Bones, arthropod fragments and plant material found in the samples were not identified.

The frequency of occurrence (FO) and percent of occurrence (PO) were used to describe the scat contents. FO refers to the percentage of fecal samples in which a prey species was found (Equation A), while PO refers to the number of times a specific item was found as percentage of all items found (Equation B; Ackerman, Lindzey, \& Hemker, 1984).

Equation A: (fi/N)x100

Equation B: $(\mathrm{fi} / \Sigma \mathrm{f} i) \times 100$

Where $\mathrm{f} i=$ number of fecal samples in which species $\mathrm{i}$ was recorded, $\mathrm{N}=$ total number of fecal samples.
Camera trap records (photos or videos) clearly showing jaguar preying on terrestrial preys, or prey species with evident marks of a jaguar attack (e.g. claw or bite marks) were used as complementary information. These records were obtained as part of the long-term camera trap monitoring program conducted by Coastal Jaguar Conservation in Tortuguero National Park, and corresponded to 12 camera trap stations located along the human-made trail running parallel to the beach from June 2012 to December 2016.

\section{RESULTS}

Of 1374 carcasses recorded (mean per year: $276.8 \pm 84.12 \mathrm{SD}$ ), $99 \%$ corresponded to sea turtles, the green sea turtle being the most common (Table 1).

Of 75 scats analyzed (mean per year: 12.50 $\pm 8.38 \mathrm{SD}), 47 \%$ consisted of a single prey item, $17 \%$ had two or more prey items, and 
TABLE 1

Jaguar Panthera onca dietary composition from carcasses and camera trap records documented in the coastal habitat of Tortuguero National Park, Costa Rica. Period: June 2012-December 2016

\begin{tabular}{|c|c|c|c|}
\hline Order & Family & Species & Records \\
\hline \multicolumn{4}{|l|}{ Mammals } \\
\hline Cingulata & Dasypodidae & Dasypus novemcinctus ${ }^{1}$ & 1 \\
\hline \multirow[t]{2}{*}{ Didelphimorphia } & Didelphidae & Didelphis marsupialis ${ }^{1}$ & 1 \\
\hline & & Philander opossum & 1 \\
\hline Perissodactyla & Tapiridae & Tapirus bairdii ${ }^{2}$ & 1 \\
\hline \multicolumn{4}{|l|}{ Reptiles } \\
\hline \multirow[t]{4}{*}{ Testudines } & Cheloniidae & Chelonia mydas & 1330 \\
\hline & & Eretmochelys imbricata & 20 \\
\hline & & Caretta caretta & 1 \\
\hline & Dermochelyidae & Dermochelys coriacea & 19 \\
\hline \multicolumn{4}{|l|}{ Birds } \\
\hline Pelicaniformes & Unknown & Unknown & 1 \\
\hline
\end{tabular}

1. Camera trap record of a jaguar holding a prey in its mouth.

2. Camera trap record of an individual with jaguar bite marks alongside its body.

prey species were unidentifiable in $36 \%$ of the samples. The white-lipped peccary was the most frequent prey found on the scat analysis. Furthermore, one scat collected on February $06,2014\left(10^{\circ} 22^{\prime} 374^{\prime \prime} \mathrm{N}-83^{\circ} 81^{\prime} 158^{\prime \prime} \mathrm{W}\right)$ contained seven claws that, due to their morphology, could belong to an adult jaguar or a puma (Puma concolor) (Table 2). Another important record was the presence of the remains of a green sea turtle hatchling in one scat collected on December 05, $2016\left(10^{\circ} 28^{\prime} 614^{\prime \prime} \mathrm{N}\right.$ - 8328'158" W).

As for the camera trap records, a total of two photos and one video, evidenced jaguar predation upon terrestrial prey species, including the nine-banded armadillo (Dasypus novemcintus), the Baird's Tapir (Tapirus bairdii) and the common opossum (Didelphis marsupialis), respectively (Table 1).

\section{DISCUSSION}

Our results were comparable with those obtained in other studies in Costa Rica (Chinchilla, 1997; Carrillo et al., 2009; Montalvo, 2012), where sea turtles and ungulate species were considered major prey species for the jaguar. In Tortuguero beach, the prey selectivity towards the green sea turtle was expected as this species is highly abundant and available throughout most of the year (Arroyo-Arce \& Salom-Pérez, 2015). Although abundance of white-lipped peccary has not yet been estimated, important records of groups of more than 20 individuals have been reported roaming within the study area (Coastal Jaguar Conservation, unpublished) year-round. Our study also highlights the variety of species (e.g. mammals, birds, reptiles) forming the jaguar's diet, reflecting its well-known generalist and opportunistic behavior (Rabinowitz \& Nottingham, 1986).

The remains of a large feline in one of the scats are of great interest, since predation among big cats has been rarely documented. For example, in Brazil jaguar infanticide (Soares et al., 2006; Tortato et al., 2017) and jaguar cannibalism (Azevedo, Costa, Concone, Pires-Da Silva, \& Verdade, 2010) has been reported. Regarding pumas, Cassaigne et al. (2016) documented an un-collared male killing and eating a collared female puma in Sonora, Mexico. Since Tortuguero beach has a high density of jaguars (yearly average of 13 individuals detected along $29 \mathrm{~km}$ of coastline; Coastal Jaguar Conservation, unpublished 
TABLE 2

Jaguar Panthera onca dietary composition from scats $(n=75)$ collected in the coastal habitat of Tortuguero National Park, Costa Rica. Period: August 2012-December 2016

\begin{tabular}{|c|c|c|c|c|}
\hline Order & Family & Species & FO $(\%)$ & $\mathrm{PO}(\%)$ \\
\hline \multicolumn{5}{|l|}{ Mammals } \\
\hline \multirow[t]{2}{*}{ Carnivora } & Procyonidae & Potos flavus & 5.33 & 6.25 \\
\hline & Felidae & Unknown ${ }^{1}$ & 1.33 & 1.56 \\
\hline \multirow[t]{2}{*}{ Cetartiodactyla } & Tayassuidae & Tayassu pecari & 20.00 & 23.44 \\
\hline & Cervidae & Mazama americana & 8.00 & 9.38 \\
\hline Primates & Atelidae & Ateles geoffroyi & 6.67 & 7.81 \\
\hline Rodentia & Cuniculidae & Cuniculus paca & 6.67 & 7.81 \\
\hline Cingulata & Dasypodidae & Dasypus novemcinctus & 1.33 & 1.56 \\
\hline Xenarthra & Bradypodidae & Unknown ${ }^{2}$ & 13.33 & 15.63 \\
\hline Didelphimorphia & Didelphidae & Philander opossum & 1.33 & 1.56 \\
\hline Lagomorpha & Leporidae & Sylvilagus brasiliensis & 2.67 & 3.13 \\
\hline \multicolumn{5}{|l|}{ Reptiles } \\
\hline Squamata & Iguanidae & Iguana iguana & 14.67 & 17.19 \\
\hline Testudines & Cheloniidae & Chelonia mydas ${ }^{3}$ & 1.33 & 1.56 \\
\hline \multicolumn{5}{|l|}{ Birds } \\
\hline Unknown & Unknown & Unknown & 4.00 & 4.69 \\
\hline
\end{tabular}

1. One scat contained seven claws of Panthera onca or Puma concolor.

2. Remains of Bradypus variegatus and/or Choloepus hoffmanni.

3. One scat with remains of a Chelonia mydas hatchling.

data), perhaps a jaguar attack upon a conspecific or a puma could have been triggered by social stress caused by multiple individuals converging in one spot or, a female defending her off-spring, or individuals defending their prey (Azevedo et al., 2010).

A major limitation of carcass analysis was the low detectability of prey remains in closed habitats, which could lead to an underrepresentation of some prey species; especially smaller ones (Tambling et al., 2012). In our study, all carcasses were recorded along the beach, which being considered an open habitat facilitated the easy detection of carcasses, and belonged to both small $(\leq 1 \mathrm{~kg} ; \mathrm{n}=2)$ and large ( $\geq 15 \mathrm{~kg} ; \mathrm{n}=1370$ ) prey species. Other factors that facilitated the detection were presence of black vultures (Coragyps atratus) around the kills and the large size of sea turtle remains (sea turtle carapace length ranges from 81-183 $\mathrm{cm}$, which varies by species). Carcasses were not detected along the trail (closed habitat), as a result of the remains being obscured by the vegetation, thus hindering detection by researchers.

Apart from green sea turtle hatchling, no other evidence of sea turtles was discovered in scat samples, despite of being one of the main components in the jaguar's diet in Tortuguero National Park. The under representation of this item could imply that jaguars only feed on sea turtles' soft tissues (e.g. internal organs), leaving intact the hard parts (e.g. carapace, head, flippers). Since consumed parts are easily decomposed within the digestive system, they are unexpected in scat samples (Hayward et al., 2016).

Field sample misidentification is another disadvantage of scat analysis. Some authors (Farrell, Roman, \& Sunquist, 2000; Davison, Birks, Brookes, Braithwaite, \& Messenger, 2002; Morin et al., 2016) suggest that identification based on sample morphology (e.g. size, shape, dietary content) may not be the most reliable way to determine the species of origin, specifically between carnivore species of similar size. In Tortuguero National 
Park, jaguar scats were identified based on the appearance but also on other signs (e.g. presence of jaguar tracks near by the samples). Furthermore, jaguar presence is frequent, while pumas are scarce in the study site (Arroyo-Arce $\&$ Salom-Pérez, 2014). Therefore, we are prone to believe that our sampling identification in the field was accurate. However, we recommend that future studies use molecular analysis of scats to minimize misidentification (Dalén, Gotherström, \& Angerbjörn, 2004).

Both carcass and scat analyses underestimated the importance of domestic animals as part of the jaguar diet. Although we did not find carcasses of domestic animals or their remains in scat content, we are aware of several confirmed jaguar attacks upon domestic cows (Bos taurus) and dogs (Canis familiaris) in the cattle ranch (Southern end of the beach), the ranger station and communities located around the study area. Therefore, we recommend the use of other methods (e.g. interviews, molecular analysis) to determine the role that domestic animals play on the feeding habits of the local jaguar population.

This is the first broad study of jaguar diet in Tortuguero National Park. Our results not only provide additional information regarding well-known predator-prey relationship between sea turtles and the jaguar, but also to understand the role that other prey species play in jaguar diet. Our results also highlight the importance of combining different methods to have a better representation of the jaguar feeding habits. Further research to complement our study should focus on calculating terrestrial prey species abundance in the study area, and collecting samples from other locations (e.g. further inland), information that would help to complement our study.

\section{ACKNOWLEDGEMENTS}

Funding was provided by The Rufford Small Grants Foundation, Idea Wild and Panthera. We gratefully acknowledge all the staff and volunteers at Global Vision International for their support throughout this investigation.
We also thank the Área de Conservación Tortuguero/SINAC for permission to work in Tortuguero National Park and for logistical support. Thanks to R. Salom-Pérez and the anonymous reviewers for their valuable comments on this paper.

\section{RESUMEN}

Hábitos de alimentación del jaguar Panthera onca (Carnivora: Felidae) en el Parque Nacional Tortuguero, Costa Rica. Aunque los estudios de dieta son una herramienta importante en la conservación de las especies, pocas investigaciones han evaluado la dieta del jaguar (Panthera onca) en Costa Rica. Por lo tanto, este estudio describe la dieta del jaguar en el Parque Nacional Tortuguero, Costa Rica, mediante el análisis y comparación de los registros de cadáveres $(\mathrm{n}=1374)$, excretas $(\mathrm{n}=75)$ y cámaras trampa $(n=3)$ colectados entre el 2012 y el 2016. Nuestros resultados indican que la dieta del jaguar consiste de al menos 20 especies; la tortuga verde (Chelonia mydas) fue la especie más importante según los datos de cadáveres, mientras que el chancho de monte (Tayassu pecari) fue la principal especie presa según el análisis de excretas. Nuestros resultados destacan la importancia de combinar diferentes métodos con el fin de obtener una descripción precisa de los hábitos alimenticios del jaguar. Se recomienda que futuros estudios estimen la abundancia del jaguar y sus especies presa terrestres, lo cual permitirá complementar nuestros resultados.

Palabras clave: Panthera onca; Chelonia mydas; Tayassu pecari; dieta; excretas; cadáver; Parque Nacional Tortuguero.

\section{REFERENCES}

Ackerman, B. B., Lindzey, F. G., \& Hemker, T. P. (1984). Cougar food habits in Southern Utah. Journal of Wildlife Management, 48(1), 147-155.

Alfaro, L. D., Montalvo, V., Guimaraes, F., Saenz, C., Cruz, J., Morazán, F., \& Carrillo, E. (2016). Characterization of attack events on sea turtles (Chelonia mydas and Lepidochelys olivacea) by jaguar (Panthera onca) in Naranjo sector, Santa Rosa National Park, Costa Rica. International Journal of Conservation Science, 7(1), 101-108.

Aranda, M. (2000). Huellas y otros rastros de los mamiferos grandes y medianos de México. Veracruz, México: Comisión Nacional para el Conocimiento y Uso de la Biodiversidad e Instituto de Ecología, A. C. Xalapa. 
Arroyo-Arce, S., \& Salom-Pérez, R. (2014). First record of Puma concolor (Carnivora: Felidae) in Tortuguero National Park, Costa Rica. Brenesia, 81-82, 115-118.

Arroyo-Arce, S., \& Salom-Pérez, R. (2015). Impact of jaguar Panthera onca (Carnivora: Felidae) predation on marine turtle populations in Tortuguero, Caribbean coast of Costa Rica. Revista de Biología Tropical, 63(3), 815-825.

Azevedo, F. C. C. (2008). Food habits and livestock depredation of sympatric jaguars and pumas in the Iguaçu National Park Area, South Brazil. Biotropica, 40(4), 494-500.

Azevedo F. C. C., Costa, R. L., Concone, H. V. B., PiresDa Silva, A., \& Verdade, L. M. (2010). Cannibalism among jaguars (Panthera onca). Southwestern Naturalist, 55(4), 597-599.

Baca, I., \& Sánchez-Cordero, V. (2004). Catálogo de pelos de guardia dorsal en mamíferos del estado de Oaxaca, México. Serie Zoología, 75(2), 383-437.

Bermúdez, F. A., \& Hernández, C. (2004). Plan de Manejo del Parque Nacional Tortuguero (Technical Report). San José, Costa Rica: Ministerio del Ambiente y Energía.

Bustamante, A. (2008). Densidad y uso de hábitat por los felinos en la parte sureste del área de amortiguamiento del Parque Nacional Corcovado, Península de Osa, Costa Rica (Master's thesis). Universidad Nacional, Costa Rica.

Carrillo, E., Fuller, T. D., \& Saenz, J. C. (2009). Jaguar (Panthera onca) hunting activity: effects of prey distribution and availability. Journal of Tropical Ecology, 25(5), 563-567.

Cassaigne, I., Medellín, R., Thompson, R. W., Culver, M., Ochoa, A., Vargas, K., Childs, J. L., ... TorresGomez, A. (2016). Diet of pumas (Puma concolor) in Sonora, Mexico, as determined by GPS kill sites and molecular identified scat, with comments on jaguar (Panthera onca). The Southwestern Naturalist, 61(2), 125-132.

Cavalcanti, S. M., \& Gese, E. M. (2010). Kill rates and predation patterns of jaguars (Panthera onca) in the southern Pantanal, Brazil. Journal of Mammalogy, 91(3), 722-736.

Chinchilla, F. (1997). La dieta del jaguar (Panthera onca), el puma (Felis concolor) y el manigordo (Felis pardalis) (Carnivora: Felidae) en el Parque Nacional Corcovado, Costa Rica. Revista de Biología Tropical, 45(3), 1223-1229.

Corrales, D., \& Cardenal, J. (2008). Ecología poblacional del jaguar (Panthera onca) y puma (Puma concolor) $y$ dieta de jaguar, en el sector Pacífico de la Cordillera de Talamanca, Costa Rica (Bachelor's thesis). Universidad Latina, Costa Rica.
Dalén, L., Gotherström, A., \& Angerbjörn, A. (2004). Identifying species from pieces of faeces. Conservation Genetics, 5, 109111.

Davison, A., Birks, J. D. S., Brookes, R. C., Braithwaite, T. C., \& Messenger, J. E. (2002). On the origin of faeces: morphological versus molecular methods for surveying rare carnivores from their scats. Journal of Zoology, 257(2), 141-143.

Farrell, L. E., Roman, J., \& Sunquist, M. E. (2000). Dietary separation of sympatric carnivores identified by molecular analysis of scats. Molecular Ecology, 9(10), 1583-1590.

Foster, R., Harmsen, B. J., \& Doncaster, C. P. (2010). Sample-size effects on diet analysis from scats of jaguars and pumas. Mammalia, 74(3), 317-321.

Gómez-Ortiz, Y., Monroy-Vilchis, O., \& MendozaMartínez, G. D. (2015). Feeding interactions in an assemblage of terrestrial carnivores in central Mexico. Zoological Studies, 54, 16. doi: 10.1186/ s40555-014-0102-7

Gonzalez-Maya, J., Navarro-Arquez, E., \& Shipper, J. (2010). Ocelots as prey items of jaguars: a case from Talamanca, Costa Rica. Catnews, 53, 11-12.

Hayward, M. W., Kamler, J. F., Montgomery, R. A., Newlove, A., Rostro-García, S., Sales, L. P., \& Van Valkenburgh, B. (2016). Prey Preferences of the jaguar Panthera onca reflect the post-pleistocene demise of large prey. Frontiers in Ecology and Evolution, 3, 148. doi: 10.3389/fevo.2015.00148

Holdridge, L. (1969). Ecología basada en zonas de vida. San José, Costa Rica: Instituto Interamericano de Ciencias Agrícolas.

Juárez, D., Estrada, C., Bustamante, M., Quintana, Y., Moreira, J., \& López, J. E. (2010). Guía ilustrada de pelos para la identificación de mamíferos medianos $y$ mayores de Guatemala. Guatemala: Universidad de San Carlos.

Klare, U., Kamler, J. F., \& Macdonald, D. W. (2011). A comparison and critique of different scat analysis methods for determining carnivore diet. Mammal Review, 41(4), 294-312.

Montalvo, V. (2012). Cambios en la abundancia, actividad temporal y dieta de jaguar (Panthera onca), otros felinos y sus presas en el Parque Nacional Santa Rosa, Area de Conservación Guanacaste, Costa Rica (Master's thesis). Universidad Nacional, Costa Rica.

Moreno, R., Kays, R. W., \& Samudio, R. (2006). Competitive release in diets of ocelot (Leopardus pardalis) and puma (Puma concolor) after jaguar (Panthera onca) decline. Journal of Mammalogy, 87(4), 808-816.

Morin, D. J., Higdon, S. D., Holub, J. I., Montague, D. M., Fies, M. L., Waits, L. P., \& Kelly, M. J. (2016). Bias in 
carnivore diet analysis resulting from misclassification of predator scats based on field identification. Wildlife Society Bulletin, 40(4), 669-677.

Pech-Canché, J. M., Sosa-Escalante, J. E., \& Koyoc, M. E. (2009). Guía para la identificación de pelos de guardia de mamíferos no voladores del estado de Yucatán, México. Revista Mexicana de Mastozoología, 13, 7-33.

Perilli, M. L. L., Lima, F., Rodrigues, F. H. G., \& Cavalcanti, S. M. C. (2016). Can scat analysis describe the feeding habits of big cats? A case study with jaguars (Panthera onca) in Southern Pantanal, Brazil. Plos One, 11. doi: 10.1371/journal.pone.0151814

Rabinowitz, A. R., \& Nottingham, B. G. (1986). Ecology and behavior of the jaguar (Panthera onca) in Belize, Central America. Journal of Zoology, 210(1), 149-159.

Rueda, P., Mendoza, G., Martínez, D., \& Rosas-Rosas, O. C. (2013). Determination of the jaguar (Panthera onca) and puma (Puma concolor) diet in a tropical forest in San Luis Potosi, Mexico. Journal of Applied Animal Research, 41, 484-489. doi: 10.1080/09712119.2013.787362

Soares T. N., Telles, M. P. C., Resende, L. V., Silveira, L., Jácomo, A. T. A., Morato, R. G., Diniz-Filho, J. A. F., ... Brondani, C. (2006). Paternity testing and behavioral ecology: a case study of jaguars (Panthera onca) in Emas National Park, central Brazil. Genetics and Molecular Biology, 29(4), 735-740.
Steenweg, R., Gillingham, M. P., Parker, K. L., \& Heard, D. C. (2015). Considering sampling approaches when determining carnivore diets: the importance of where, how, and when scats are collected. Mammal Research, 60(3), 207-216.

Tambling, C. J., Laurence, S. D., Bellan, S. E., Cameron, E. Z., du Toit, J. T., \& Getz, W. M. (2012). Estimating carnivoran diets using a combination of carcass observations and scats from GPS clusters. Journal of Zoology, 286(2), 102-109.

Tortato, F. R., Devlin, A. L., Hoogesteijn, R., Júnior, J. A. M., Frair, J. L., Crawshaw, P. G., Izzo, T. J., \& Quigley, H. B. (2017). Infanticide in a jaguar (Panthera onca) population - does the provision of livestock carcasses increase the risk? Acta Ethologica, 20(1), 69-73.

Veríssimo, D., Jones, D. A., Chaverri, R., \& Meyer, S. R. (2012). Jaguar Panthera onca predation of marine turtles: conflict between flagship species in Tortuguero, Costa Rica. Oryx, 46(3), 340-347.

Waits, L. P., \& Paetkau, D. (2005). Noninvasive genetic sampling tools for wildlife biologists: a review of applications and recommendations for accurate data collection. The Journal of Wildlife Management, 69(4), 1419-1433.

Weckel, M., Giuliano, W., \& Silver, S. (2006). Jaguar (Panthera onca) feeding ecology: distribution of predator and prey through time and space. Journal of Zoology, 270(1), 25-30. 